\title{
TITLE:
}

\section{ON SOME ECHINOIDS FOUND IN SURUGA BAY}

AUTHOR(S):

Morishita, Akira

\section{CITATION:}

Morishita, Akira. ON SOME ECHINOIDS FOUND IN SURUGA BAY.

PUBLICATIONS OF THE SETO MARINE BIOLOGICAL LABORATORY 1969, 16(6): 363-379

ISSUE DATE:

1969-03-31

URL:

http://hdl.handle.net/2433/175565

RIGHT: 


\title{
ON SOME ECHINOIDS FOUND IN SURUGA BAY
}

\author{
AKIRA MORISHITA \\ Institute of Earth Sciences, Faculty of Science, Nagoya University
}

With Plates XXI-XXV, 1 Text-figure and 1 Table

\section{Introduction}

A benthic biological survey in Suruga Bay by the research boat "Tansei Maru", attached to the Ocean Research Institute, Tokyo University, was carried out in July, 1965. The results of the survey were reported in a paper by Dr. Yaichirô OKADA and other members of the Fisheries Research Laboratory, Tokai University in March, 1966.

The deep-sea animals given in that report were as follows; Annelida-11 species, Porifera-1, Coelenterata-9, Bryozoa-1, Brachiopoda-1, Cephalopoda-1, Pelecypoda13, Gastropoda-20, Scaphopoda-5, Arthropoda-22, Asteroidea-8, Ophiuroidea-17, Echinoidea-12, Holothuroidea-7, Pisces-3. The opportunity to observe the specimens of echinoids has been given to the present writer since three years ago.

The writer wishes to acknowledge his indebtedness to Dr. Yaichirô Okada and other members of the Fisheries Research Laboratory, Tokai University for their kind permission to examine the specimens and to publish the present paper, to Dr. Huzio Utinomi, Dr. Takasi Tokioka and other members of the Seto Marine Biological Laboratory for the opportunity to publish this paper, and to Professor Heiichi Takehara of the Institute of Earth Sciences, Nagoya University for his incessant encouragement.

\section{Dredging Stations of Echinoids}

There were found 14 genera and 15 species of echinoids in the collections by the benthic biological survey of 1965 in Suruga Bay. Their species names are shown in Table 1, with the details of the dredging stations: station number, position (latitude and longitude), depth (in meter), and bottom materials, and further abundancy of echinoids.

Publ. Seto Mar. Biol. Lab., XVI (6), 363-379, 1969. (Article 27) 
Table 1. List of Echinoids found in Suruga Bay.

\begin{tabular}{|c|c|c|c|c|c|}
\hline Species & Nr. & Position & $\operatorname{Depth}(\mathrm{m})$ & Bottom & Abundancy \\
\hline Tromikosoma tenue & 8 & $\begin{array}{l}34^{\circ}-40.7^{\prime} \mathrm{N} \text { Senoumi } \\
138^{\circ}-23.6^{\prime} \mathrm{E}\end{array}$ & $60-510$ & mud & 1 \\
\hline Asthenosoma ijimai & 8 & & $510-600$ & mud & 1 \\
\hline Stereocidaris japonica & ; 10 & $\begin{array}{l}34^{\circ}-43.0^{\prime} \mathrm{N} \text { Senoumi } \\
138^{\circ}-28.8^{\prime} \mathrm{E}\end{array}$ & $180-230$ & $\begin{array}{l}\text { shell } \\
\text { granule }\end{array}$ & many \\
\hline Caenopedina mirabilis & 10 & & $180-230$ & $\begin{array}{l}\text { shell } \\
\text { granule }\end{array}$ & 1 \\
\hline Pseudechinus huttoni & 2 & $\begin{array}{l}34^{\circ}-49.0^{\prime} \mathrm{N} \text { off Tago } \\
138^{\circ}-47.8^{\prime} \mathrm{E}\end{array}$ & 310 & mud & 1 \\
\hline Laganum fudsiyama & 2 & & 310 . & mud & 3 \\
\hline Pourtalesia laguncula & 2 & & 310 & mud & $?$ \\
\hline Lovenia elongata & 2 & & 300 & mud & many \\
\hline$"$ & 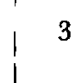 & $\begin{array}{r}34^{\circ}-49.5^{\prime} \mathrm{N} \text { off Tago } \\
138^{\circ}-41.2^{\prime} \mathrm{E}\end{array}$ & $500-630$ & $\begin{array}{l}\text { cobble } \\
\text { stone }\end{array}$ & i \\
\hline Echinocardium cordatum & 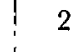 & 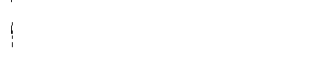 & $300-730$ & $\begin{array}{l}\text { stone } \\
\text { mud }\end{array}$ & 2 \\
\hline Schizaster lacunosus & 8 & 1 & $60-510$ & mud & many \\
\hline$"$ & 18 & $\begin{array}{c}35^{\circ}-04.5^{\prime} \mathrm{N} \text { off Miho } \\
138^{\circ}-44.8^{\prime} \mathrm{E}\end{array}$ & $360-580$ & mud & many \\
\hline Moira lachesinella & 2 & & $300-730$ & $\begin{array}{l}\text { stone } \\
\text { mud }\end{array}$ & many \\
\hline Brissopsis luzonica & 2 & & 300 & mud & many \\
\hline Brissopsis bengalensis & 2 & i & $510-580$ & mud & $?$ \\
\hline Brissus latecarinatus & $!$ & & 300 & $\begin{array}{l}\text { stone } \\
\text { mud }\end{array}$ & 1 \\
\hline Gymnopatagus valdiviae & 10 & & $180-230$ & $\begin{array}{l}\text { shell } \\
\text { granule }\end{array}$ & 1 \\
\hline
\end{tabular}

According to H. Aokr, T. Yoshinara and M. Hoshino, the submarine topography of Suruga Bay is specialized by the elevation of N-S direction and the two deeps on both sides of the elevation. Further, there are several depressions at the various points of the floor, but as shown in Figure 1 neither continental shelves in the interior part of the bay, nor any submarine valleys on the west side of Izu Peninsula.

Echinoids were collected from five $(2,3,8,10,18)$ of the eighteen dredging stations, from the $60-730 \mathrm{~m}$ deep of the continental slopes. Most species were obtained from the muddy bottoms except three cases from the shelly, granule sandy or cobbly bottoms. Especially, Stereocidaris japonica, Lovenia elongata, Schizaster lacunosus, Brissopsis luzonica and Moira lachesinella were found in large numbers.

Tromikosoma tenue, Asthenosoma ijimai, Moira lachesinella, Brissus latecarinatus and Echinocardium cordatum were identified by Y. OKADA, but not by the present writer. 


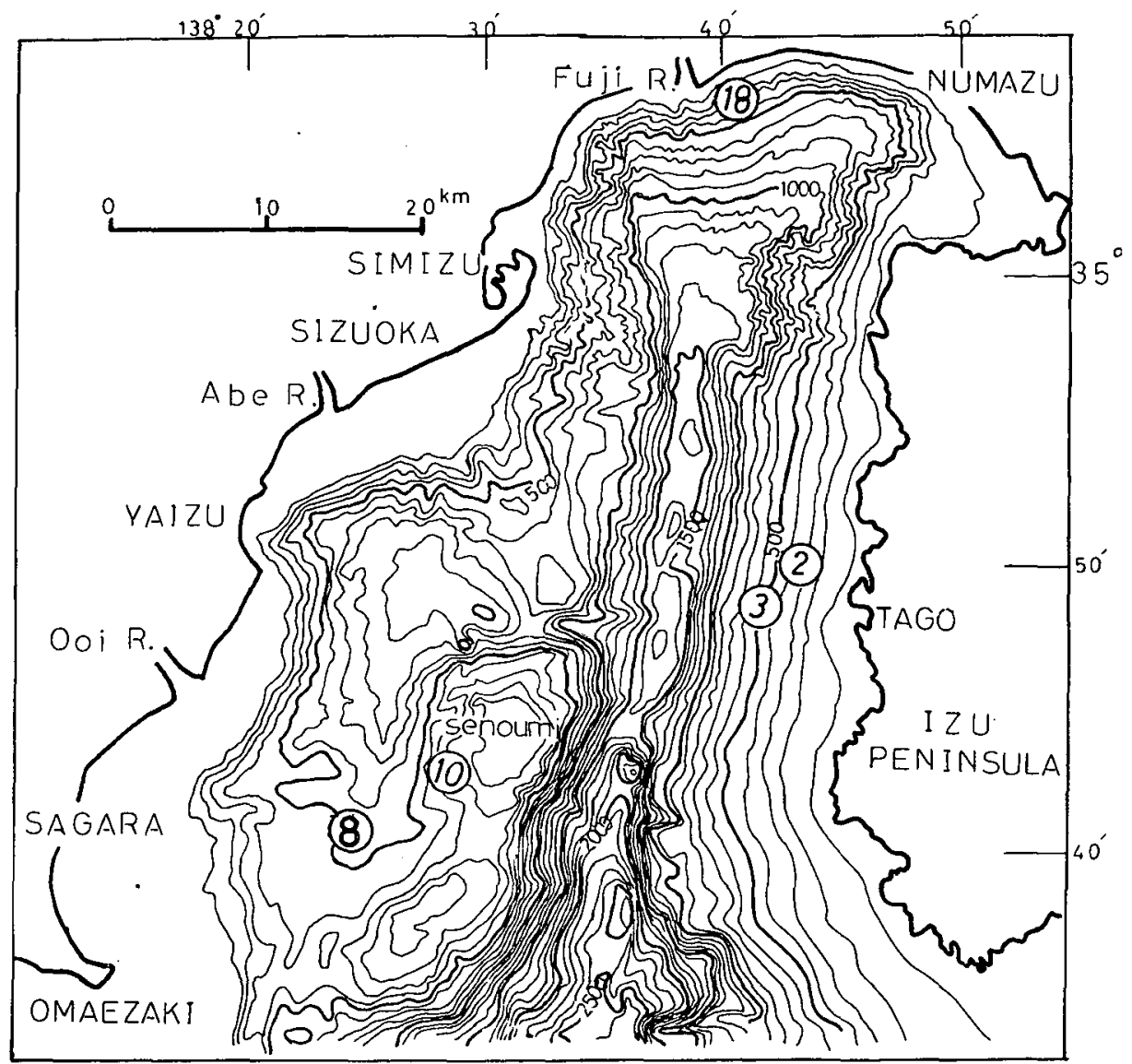

Fig. 1. Submarine topographic map of Suruga Bay, with the dredging stations of echinoids.

\section{Description of Species}

\section{Order Cidaroida Claus- Family Cidaridae Gray \\ Genus Stereocidaris POMEL}

Stereocidaris japonica (DöDERLEIN)

(Pl. XXI, Figs. 1-2;Pl. XXII, Figs. 1-2)

1885 Stereocidaris japonica. L. Döderlein, Seeigel von Japan und Liukiu Inseln, Arch. Naturg., 51, P. 76.

1898 Cidaris tenuispinus. S. Yoshiwara, Japanese Echinoids, Zool. Mag., 10, P. 57.

1904 Cidaris tenuispinus. S. Yoshiwara, op. cit., 16, pl. 1, figs. 8-10.

1928 Stereocidaris japonica. Th. Mortensen, A Monograph of the Echinoidea, I, P. 280, pls. 28, figs. $1-10 ; 70$, fig. 8;82, figs. 11-17.

1954 Stereocidaris japonica. H. Uтімомi, A Check List of Echinoids found in the Kii Region, Publ. Seto 
Mar. Biol. Lab., 3(3), P. 341.

1968 Stereocidaris japonica. S. Nisryama, The Echinoids Fauna from Japan and Adjacent Regions, II, P. 319.

Two specimens of this species are at the writer's disposal.

The test is medium in size, circular in shape, and rather low. The oral surface of the test is strictly flat and the peristomial edge is slightly incurved. The ambulacra are narrower than the interambulacra. The interporiferous zones are rather broader than the poriferous zones. The pore-pairs are arranged.in single, regular series. The interambulacral plates are large, sharply cut at edges and abutted on each other. There is the large areole around a single primary tubercle on each interambulacral plate.

The apical system is somewhat larger than the peristome. The genital and ocular plates are covered by tubercles. The test is stout and yellowish-brown in colour. The primary spines (radioles) are large, long, and furnished with longitudinal rows of granules. The secondary spines are generally flat in shape. There are many scrobicular spines around the primaries. The colour of the primaries is greenish gray.

$\begin{array}{lcc} & \text { Specimen A } & \text { Specimen B } \\ \text { Test- Horizontal diameter: } & 26.8 \mathrm{~mm} & 28.2 \mathrm{~mm} \\ \text { Vertical diameter: } & 17.7 \mathrm{~mm} & 17.0 \mathrm{~mm} \\ \text { Apical system-Diameter: } & 11.5 \mathrm{~mm} & 11.7 \mathrm{~mm} \\ \text { Peristome- Diameter: } & 10.0 \mathrm{~mm} & 9.4 \mathrm{~mm} \\ \text { Primaries-Length: } & 45.0 \mathrm{~mm} & 40.0 \mathrm{~mm}\end{array}$

Three other species and three subspecies of this genus are known from Japan and adjacent regions, they are: Stereocidaris grandis (DöDERLEIN), Stereocidaris grandis hyatorina MORTEnsen, Stereocidaris microtuberculata (Yoshiwara), Stereocidaris indica philippinensis Mortensen, Stereocidaris sceptriferoides DöDERlein, and Stereocidaris sceptriferoides lanceolata MoRTENSEN.

Dredging station: Number: 10. Position: $34^{\circ}-43.0^{\prime} \mathrm{N}, 138^{\circ}-28.8^{\prime} \mathrm{E}$, Senoumi. Depth: $180-230 \mathrm{~m}$. Bottom: shell and granule sand. Abundancy: Many specimens were collected.

\section{Order Diadematoida DunCan-Suborder Pedinoina Mortensen-}

Family Pedinidae Pomel

Genus Caenopedina A. Agassiz

Caenopedina mirabilis (DÖDERLEIN)

(Pl. XXII, Figs. 3-4)

1885 Hemipedina mirabilis. L. Döderlein, Seeigel von Japan und Ljukiu Inseln, Arch. Naturg., 51, P. 24 . 
1898 Hemipedina mirabilis. S. Yoshiwara, Japanese Echinoids, Zool. Mag., 10, P. 330.

1904 Coenopedina mirabilis. Th. Mortensen, Echinoidea, Danish Expedition to Siam, Mem. Acad. Sci., Copenhague, 7(1), P. 34, pls. III, fig. 12; IV,3,5,6.

1905 Hemipedina mirabilis. S. Yoshiwara, op. cit., 17, pl. 5, fig. 5.

1912 Caenopedina mirabilis. H. L. Clark, Hawaiian and other Pacific Echini, 1, Mem. Museum Comp. Zool., 34(4), p. 221, pls. 91, figs. 14-17; 105, fig. 8 .

1937 Caenopedina mirabilis. S. Nisryama, Annotated List of Echinoids dredged from the Pacific Coast of Tiba Prefecture, Rec. Oceanogr. Works, Japan, 9(1), P. 50.

1940 Caenopedina mirabilis. Th. Mortensen, A Monograph of the Echinoidea, III-1, P. 99, pls. II, figs. 13-15;III, fig. 2;LXVI, figs. 10-22;LXVII, fig. 17.

1954 Caenopedina mirabilis. H. Utinomi, A Check List of Echinoids found in the Kii Region, Publ. Seto Mar. Biol. Lab., 3(3), P. 343.

1968 Caenopedina mirabilis. S. Nisryama, The Echinoids Fauna from Japan and Adjacent Regions, II, P. 328.

Only one specimen of this species is at the writer's disposal.

The test is small in size, low, and flattened above but not sunken towards the peristome. It is perfectly round in outline. The primary ambulacral tubercles form a regular series in each column. The interambulacral primaries are few, very large and their areola are broadly confluent. The secondary tubercles are very abundant.

The apical system are distinctly dicyclic. The anal opening is nearly central, and covered by small spines. The peristome is about the same in size as the apical system. The gill-slits are not deep. The largest spine is $14 \mathrm{~mm}$ long. There are some globiferous, tridentate, ophicephalous and triphyllous pedicellaria. The test is fragile. The colour of test is greenish brown, and the primary spines are banded.

Horizontal diameter: $18.2 \mathrm{~mm}$

Vertical diameter : $7.0 \mathrm{~mm}$

Another species of this genus Caenopedina pulchella is known from Japan and adjacent region.

Dredging station: Number: 10. Position: $34^{\circ}-43.0^{\prime} \mathrm{N}, 138^{\circ}-28.8^{\prime} \mathrm{E}$, Senoumi. Depth: 180-230 m. Bottom: shell \& granule sand. Abundancy: one specimen only.

\title{
Order Echinoida Claus-Suborder Temnopleuroina Mortensen-
}

\author{
Family Temnopleuridae A. Agassiz
}

\section{Genus Pseudechinus MorTensen}

\section{Pseudechinus huttoni BENHAM}

(Pl. XXIII, Figs. 1-3)

1912 Parechinus huttoni. H. L. Clark, Hawaiian and other Pacific echini, I, Mem. Museum Comp. Zool., 34(4), P. 274.

1943 Pseudechinus huttoni. Th. Mortensen, A Monograph of the Echinoidea, III-2, P. 238, pls. XVII, figs. 25-28; XLVII, fig. 28. 
Only one specimen of this species is at the writer's disposal. The left side of the test is broken.

The test is moderate in size, hemispherical, rather high and the oral side somewhat flattened. The apical system is dicyclic and no ozular plates are inserted. The subanal plate is distinct; the anal opening is eccentric posteriorly, and displaced towards the genital plate I. Apart from the buccal plates the buccal membrane is naked. The gill slits are rather shallow. The test is fragile and whitish in colour.

The ambulacral areas are narrow, and the intcrambulacral areas broad. The primary ambulacral and interambulacral tubercles are fairly conspicuous. There is a primary tubercle (and spine) on every ambulacral plate. The pore-arcs are more or less erect. The pore-zones neither widened, nor narrowed at the peristomial edge.

The primary spines are moderately long and about $20 \mathrm{~mm}$ in the longest ones.

Horizontal diameter: $51.0 \mathrm{~mm}$

Vertical diameter : $35.7 \mathrm{~mm}$

According to Th. Mortensen, the genus Pseudechinus is known from AustraliaNew Zealand and the subantarctic region. Thus, this is the first discovery in Japanese region.

Dredging station: Number: 2. Position: $34^{\circ}-49.0^{\prime} \mathrm{N}, 138^{\circ}-47.8^{\prime} \mathrm{E}$, off Tago, Izu Peninsula. Depth: $310 \mathrm{~m}$. Bottom: mud(soft). Abundancy: one specimen only.

\section{Order Clypeasteroida A. AGASSIz-Suborder Laganoina}

\section{MORTENSEN-Family Laganidae DESOR}

Genus Laganum LINK

\section{Laganum fudsiyama DöDERLEIN}

$$
\text { (P1. XXIV, Figs. 1-4) }
$$

1885 Laganum fudsiyama. L. Döderlein, Seeigel von Japan und Liukiu Inseln, Arch. Naturg., 51, P.32.

1903 Laganum fudsiyama. S. Tokunaga, Fossil Echinoids of Japan, Jour. Coll. Sci., Tokyo, 17(12), P. 11.

1907 Laganum fudsiyama. S. Yoshiwara, Japanese Echinoids, Zool. Mag., 19, pl. 16, figs. 1-4.

1914 Laganum fudsiyama. 'Th. Mortensen, On the Development of some Japanese Echinoderms, Annot. Zool. Japon., 8, p. 547.

1914 Laganum fudsiyama. H. L. Clark, Hawaiian and other Pacific echini, Mem. Museum Comp. Zool., 46, pls. 124, figs. 13-16;127, figs. 7-8;140, figs. 3-4;141, figs. 4-9.

1925 Laganum fudsiyaam. H. L. Clark, Cat. Rec. Sea-urchins Brit. Mus., P. 158.

1937 Laganum diploporum. S. NisiYama, Annotated List of Echinoids dredged from the Pacific Coast of Tiba Prefecture, Rec. Oceanogr. Works in Japan, 9, P. 56.

1937 Jacksonaster fudsiyama. A. JeAnnet u. R. Martin, Ueber Neozoische Echinoidea aus dem Niederländisch Archipel., Leid. Geol. Mededl., 8, P. 250.

1948 Laganum fudsiyama. Th. Mortensen, A Monograph of the Echinoidea, IV-2, P. 338, pls. LIV, figs. 5-6, 10-13;LXX, figs. 8-9, 14-15.

1954 Laganum fudsiyama. H. Utinomi, A Check List of Echinoids found in the Kii Region, Publ. Seto Mar. Biol. Lab., 3(3), P. 354. 
1968 Laganum fudsiyama. S. Misiyama, The Echinoids Fauna from Japan and Adjacent regions, II, PP. 71,375 .

Two specimens of this species are at the writer's disposal.

The test is medium in size. The aboral surface of the test is gradually elevated from the distal end of the ambulacral petals toward the summit, like Mt. Fuji (Fujiyama), though not so high. The margin of the test is not so thin, but not swollen. The longitudinal diameter is slightly longer than the transverse one.

The apical system is nearly central; the genital pores are six, as double ones are present in the odd posterior interambulacrum.

The oral surface is almost flat, but somewhat sunken toward the peristome. The peristome is pentagonal and situated slightly anterior to the centre of the test $20.3 \mathrm{~mm}$ from the front). The periproct is pentagonal, situated near the edge of the test, 4.3 $\mathrm{mm}$ apart from the posterior margin.

The test is rather strong, although the oral side of one specimen is found broken. The ambulacral petals are narrow, lanceolate, open at the extremities, and extending over one-half of the radius. The anterior paired petals are slightly shorter than the other three. All the ambulacral petals are almost equal in width. The poriferous zones are very narrow and the interporiferous zones broad. The pore rows are divergent at first, then convergent at about one-third of the petal length. The pores are about 36 in each row. They are small and indistinctly conjugate; sometimes the outer pores are larger than the innner. The ambulacral furrows are not so clearly marked, but extend straight halfway to the margin of the test. The interambulacral areas are quite broad.

The tubercles on the oral surface are about $0.2 \mathrm{~mm}$ in diameter and more or less larger than those on the aboral surface. The primary spines are $1.5 \mathrm{~mm}$ long on the aboral and $4 \mathrm{~mm}$ long on the oral side, and scattered. The primaries around the peristome are dense and almost club-shaped. The spines along the margin of the test appear like a fringe. The secondary spines are very fine, and appear like a velvet.

The colour of the test is green.

Specimen A

Test Length: $44.3 \mathrm{~mm}$. Width: $42.8 \mathrm{~mm}$. Height: $8.5 \mathrm{~mm}$.

Odd Amb. Length: 13. 4mm. Width: $3.5 \mathrm{~mm}$. Width of interpor. zone: $1.9 \mathrm{~mm}$.

Ant. Paired Amb. Length: $13.0 \mathrm{~mm}$. Width: $3.4 \mathrm{~mm}$. Width of interpor. zone :2.0 mm.

Post. Paired Amb. Length: $13.4 \mathrm{~mm}$. Width: $3.6 \mathrm{~mm}$. Width of interpor. zone: $2.0 \mathrm{~mm}$.

\section{Specimen B}

Test Length:35.3 mm. Width:33.7 mm. Height:7.3 mm.

Four other species of this genus are known from Japan and adjacent region; 
they are: Laganum laganum (LESKE), Laganum depressum LEsson, Laganum putnami A. Agassiz, Laganum boninense DöDERLEIN.

Dredging station: Number: 2. Position: $34^{\circ}-49.0^{\prime} \mathrm{N}, 138^{\circ}-47.8^{\prime} \mathrm{E}$, off Tago, Izu Peninsula. Depth: $310 \mathrm{~m}$. Bottom: mud(soft). Abundancy: Three specimens were collected at a spot off Tago.

\section{Order Spatangoida Claus-Suborder Urechinoina H.L. CLARK-}

Family Pourtalesiidae A. Agassiz

Genus Pourtalesia A. AgAssiz

Pourtalesia laguncula A. AgAssiz

(Pl. XXIV, Figs. 5-6)

1879 Pourlalesia laguncula. A. Agassiz, Preliminary Report on the "Challenger" Echini, Proc. Amer. Acad. Arts \& Sci., 14, P. 205.

1881 Pourtalesia laguncula. A. Agassiz, Report on the Scientific Results of the Voyage H. M. S. Challenger, Zoology, 3(9), pls. XXII, figs. 7-15;XXXI, figs. 1-6;XXXIX, fig. 35;XL, figs. 61-62;XLI, fig. 53.

1900 Pourtalesia laguncula. S. Yoshiwara, Japanese Echinoids, Zool. Mag., 12, P. 405.

1908 Pourtalesia laguncula. S. Yoshiwara, op. cit., 20, pl. 21, figs. 15-17.

1925 Pourtalesia laguncula. H. L. Clark, Cat. Rec. Sea-urchins Brit. Mus., P. 192.

1950 Pourtalesia laguncula. Th. Mortensen, A Monograph of the Echinoidea, V-1, P. 147.

1954 Pourtalesia laguncula. H. Utinomi, A Check List of Echinoids found in the Kii Region, Publ. Seto Mar. Biol. Lab., 3(3), P. 355.

1968 Pourtalesia laguncula. S. Nisryama, The Echinoids Fauna from Japan and Adjacent Regions, II, p. 387.

Only one specimen of this species is at the writer's disposal.

The test is rather small in size, nearly cylindrical, but more or less bottle-shaped. The anterior part of the test is not widened, and not forming a head like portion; the frontal edge is almost vertical. The posterior end of the test forms a hood over the periproct. The width of the test is about one-half of the length. The sides of the test are not parallel with each other. The oral surface is not flattened, rather convex. The apical system is conspicuously close to the anterior edge; the genital pores are four. The peristome is situated in a constriction of the antercor edge on the oral side. The periproct is supramarginal in the odd posterior interambulacrum. The subanal fasciole in the subanal rostrum. The test is fragile, and the colour is violet or dark purplish.

All the ambulacra are simple and uniporous. The bivial ambulacra are discontinuous and interrupted by the interambulacra 1 and 4, meeting in the midline on the oral side. The primary tubercles are perforate and crenulate.. The primary spines are about $2 \mathrm{~mm}$ in length.

Test Length:24.2 mm. Width:12.3 mm. Height:11.8 mm.

Only this species of the genus Pourtalesia is known from Japan and adjacent region. 
Dredging station: Number:2. Position: $34^{\circ}-49.0^{\prime} \mathrm{N}, 138^{\circ}-47.8^{\prime} \mathrm{E}$, off Tago,

Izu Peninsula. Depth:310 m. Bottom:mud(soft).

\title{
Suborder Spatangoina CLAuS-Family Loveniidae LAMBERT
}

\author{
Genus Lovenia DESOR \\ Lovenia elongata (GRAY)
}

(Pl. XXIV, Figs. 7-9)

1881 Lovenia elongata. A. Agassiz, Report on the Scientific Results of the Voyage H. M. S. Challenger, Zoology, 3(9), p. 175, pls. XXXIX, fig. 13;XL, figs. 45-46.

1885 Lovenia elongata. L. DöDerlein, Seeigel von Japan und Liukiu Inseln, Arch. Naturg., 51, P. 35.

1906 Lovenia elongata. J. W. Gregory, Fossil Echinoids from Sinai and Egypt, Geol. Mag., (5) III, P. 255.

1908 Lovenia elongata. S. Yoshrwara, Japanese Echinoids, Zool. Mag., 20, pl. 21, figs. 5-8.

1923 Lovenia elongata. H. L. Clark, The Echinoderm Fauna of South Africa, Ann. S. African Mus., XIII, P. 404.

1925 Lovenia elongata. H. L. CLARk, Cat. Rec. Sea-Urchins Brit. Mus., P. 230.

1931 Lovenia elongata. H. IKeDA, Morphological Change occurring with the Growth of the Test in the Heart-Urchin, Lovenia elongata, Annot. Zool. Japon., 13(3), P. 243, pl. 14.

1933 Lovenia elongata. H. IKEDA, Note on a single-spined Specimen of the Heart-Urchin, Lovenia elongata, op. cit., 14(1).

1951 Lovenia elongata. Th. Mortensen, A Monograph of the Echinoidea, V-2, P. 97, pls. VII, figs. $1-10$;VIII, fig. 1 ; XII, fig. 5;XLVII, figs. 10-23.

1954 Lovenia elongata. H. Utinomi, A Check List of Echinoids found in the Kii Region, Publ. Seto Mar. Biol. Lab., III(3), P. 355.

1966 Lovenia triforia. Y. OKADA et al., Preliminary Report of the Benthic Biological Survey in Suruga Bay, Jour. Fac., Oceanogr., Tokai Univ., 1, PP. 139, 141.

1968 Lovenia elongala. S. Nisiyama, The Echinoids Fauna from Japan and Adjacent Regions, II, P. 397.

Only one specimen of this species is at the writer's disposal.

The test is small in size and somewhat heart-shaped in outline, broad anteriorly, and narrowing towards the posterior end. The greatest width is at the posterior paired interambulacra. The frontal depression of the test is remarkable and broad. The posterior end is truncate and concave. The test is low and the odd ambulacrum and interambulacrum on the aboral side are slightly raised. The greatest height is near the posterior end. The apical system is slightly eccentric anteriorly. The genital pores are four.

The oral surface is nearly flat and the plastron is not elevated. The peristome is eccentric anteriorly and in shape slender transversely. The labrum is distinct, but without the prominent edge. The periproct is situated near the summit of the posterior truncated surface, sinall, and circular. The subanal fasciole is distinct and broad, but the internal fasciole is obscure. The test is fragile, and rather white in 
colour.

All the ambulacra are narrow and petaloid. The odd anterior ambulacrum is a simple series and almost straight. The pores are small and 15 in number. All the paired ambulacra are nearly equal in length, and slightly open at the extremities. Near their extremities the anterior paired ambulacra are divergent, while the posterior ones convergent slightly. The pore-pairs are 11 in the anterior paired ambulacra and 10 in the posterior ones respectively. The interporiferous zones are rather broad throughout all ambulacra. The posterior interambulacral pair is the broadest.

There are a few large primary tubercles and spines in the paired interambulacra and in the subanal fasciole. The longest primary spines are about $9 \mathrm{~mm}$.

Test Length:34.5 mm. Width:27.8 mm. Height:12.5 mm.

Odd Amb. Length:10.2 mm. Width:2.5 mm.

Ant. Paired Amb. Length:8.5 mm. Width:2.2 mm.

Post. Paired Amb. Length:8.5 mm. Width:2.5 mm.

Three other species of this genus are known from Japan and adjacent region, they are: Lovenia gregalis Alcock, Lovenia subcarinata (GARY), Lovenia triforis KOEHLER.

Dredging stations: Number: 2. Position: $34^{\circ}-49.0^{\prime} \mathrm{N}, 138^{\circ}-47.8^{\prime} \mathrm{E}$, off Tago, Izu Peninsula. Depth: $300 \mathrm{~m}$. Bottom: mud (soft). Abundancy: Many specimens were collected.

Number: 3. Position: $34^{\circ}-49.5^{\prime} \mathrm{N}, 138^{\circ}-41.2^{\prime} \mathrm{E}$, off Tago, Izu Peninsula. Depth: 500-630 m. Bottom :cobble. Abundancy: Only one specimen was collected.

\section{Family Schizasteridae LAMBERT \\ Genus Schizaster L. Agassiz \\ Schizaster lacunosus (LINNAEUS) \\ (Pl. XXIV, Figs. 10-12)}

1881 Schizaster japonicus. A. Agassiz, Report on the Scientific Results of the Voyage H. M. S. Challenger, Zoology, 3(9), P. 202, pls. XXXVI, figs. 8-13;XLIII, fig. 26;LXV, figs. 7-10.

1900 Schizaster japonicus. S. Yoshiwara, Japanese Echinoids, Zool. Mag., 12, P. 398.

1907 Schizaster japonicus. S. Yoshiwara, op. cit., 19, pl. 17, figs. 10-14.

1924 Schizaster lacunosus. H. L. CLARK, Echinoderms from the South African Fisheries and Marine Biological Survey, pt. 1, Fish. \& Mar. Biol. Survey, Rep., 4, P. 12.

1925 Schizaster lacunosus. H. L. CLARK, Cat. Rec. Sea-Urchins Brit. Mus., P. 210.

1951 Schizaster lacunosus. Th. Mortensen, A Monograph of the Echinoidea, V-2, P. 300, pls. XXI, figs. 5-10, 14-18;LIV, figs. 1-3, 5, 7-9, 12, 14-17.

1954 Schizaster lacunosis. H. Utrnomi, A Check List of Echinoids found in the Kii Region, Publ. Seto Mar. Biol. Lab., III(3), P. 355.

1968 Schizaster lacunosus. S. NisiYama, The Echinoids Fauna from Japan and Adjacent Regions, II, P. 404.

Two specimens of this species are at the writer's disposal, one of them is broken. 
The test is medium in size, and roughly elongate oval in outline. The test is deeply notched by the anterior sulcus and the vertex is situated near the posterior margin. The aboral surface is gradually sloped down from the vertex towards the anterior margin; the posterior margin is truncated vertically. The longitudinal diameter is slightly longer than the transverse. The apical system is eccentric posteriorly (13.2 $\mathrm{mm}$ apart from the posterior margin) and also slightly eccentric anteriorly from the vertex. The genital pores are only two.

The oral surface is slightly convex. The plastron is broad and not so much elevated. The peristome is lunular in shape and very eccentric anteriorly $(6.8 \mathrm{~mm}$ from the anterior margin). The labrum is fairly prominent, with the edges upturned. The periproct is placed at the summit of the posterior truncation. The peripetalous and latero-anal fascioles are distinct, and the latter makes a deep bend below the periproct. The test is fragile and grayish brown in colour.

The odd anterior ambulacrum is situated in a deep broad groove and widest at the middle, showing a tendency of narrowing anteriorly. The pores are arranged in simple and regular series. The paired ambulacra are petaloid and situated in shallow grooves. The anterior paired ambulacra are longer than the posterior ones in curved in the neighbourhood of the apical system, keeping an angle of $50^{\circ}$ between them at the apical system, and slightly open at their extremities. The interporiferous zones are very narrow $(0.8 \mathrm{~mm}$ in width). The pore-pairs are 32 . The posterior paired ambulacra are shorter, less than one half of the anterior ones, more or less curved outwards forming an angle of $120^{\circ}$ between them at the apical system and slightly open at their extremities.. The width of the interporiferous zones $(0.8 \mathrm{~mm})$ is narrower than the poriferous zones. The pore-pairs are 17 . The anterior paired interambulacra make sharply keel-like narrow ridges near the apical system against the grooves including ambulacra. The other three interambulacra form similarly lower keels, too.

The tubercles in the plastron are the largest. The primary spines are 2 to $3 \mathrm{~mm}$ long.

Test Length:33.4 mm. Width:31.2 mm. Height:18.5 mm.

Odd Amb. Length:19.2 mm. Width:5.5 mm.

Ant. Paired Amb. Length:16.5 mm. Width:4.2 mm. Width of interpor. zone:0.8 mm.

Post. Paired Amb. Length:6.8 mm. Width: $3.8 \mathrm{~mm}$. Width of interpor. zone: $0.8 \mathrm{~mm}$.

Only this species of the genus Schizaster is known from Japan and adjacent region.

Dregding stations: Number:8. Position: $34^{\circ}-40.7^{\prime} \mathrm{N}, 138^{\circ}-23.6^{\prime} \mathrm{E}$, around Senoumi. Depth:60-510 m. Bottom:mud(solid). Abundancy:Many specimens were collected.

Number:18. Position: $35^{\circ}-04.5^{\prime} \mathrm{N}, 138^{\circ}-44.8^{\prime} \mathrm{E}$, off Miho. Depth:360-580 m. Bottom:mud(soft). Abundancy:Many specimens were collected. 


\title{
Family Brissidae GraY
}

\author{
Genus Brissopsis L. Agassiz \\ Brissopsis luzonica (GRAY)
}

(PI. XXV, Figs. 5-7)

1881 Brissopsis luzonica. A. Agassiz, Report on the Scientific Results of the Voyage H. M. S. Challenger, Zoology, 3(9), P. 189.

1885 Brissopsis luzonica. L. Döderlein, Seeigel von Japan und Liukiu Inseln, Arch. Naturg., 51, P. 36.

1907 Brissopsis luzonica. S. YoshiwarA, Japanese Echinoids, Zool. Mag., 19, pl. 19, figs. 7-10.

1925 Brissopsis luzonica. H. L. Clark, Cat. Rec. Sea-Urchins Brit. Mus., P. 213.

1951 Brissopsis luzonica. Th. Mortensen, A Monograph of the Echinoidea, V-2, P. 397.

1951 Brissopsis luzonica. Th. Mortensen, A Monograph of the Echinoidea, V-2, P. 397, pls. XXXII, figs. 2-4, 12-14, 19, 21 ; XXXIX, fig. 12; LVI, figs. 2, 4, 5, 8-11, 13-15, 18-29.

1954 Brissopsis luzonica. H. Utinomi, A Check List of Echinoids found in the Kii Region, Publ. Seto Mar. Biol. Lab., III(3), P. 356.

1968 Brissopsis luzonica. S. Nisiyama, The Echinoids Fauna from Japan and Adjacent Regions, II, P. 406.

Two specimens of this species are at the writer's disposal, and one of them is broken.

The test is rather small in size, elongate ovoid in shape, and notched at the anterior paired ambulacra. The frontal depression of the test is remarkable. The posterior end is distinctly truncate and concave. The test is rather low, with the greatest height at the posterior ambitus. The apical system is slightly eccentric anteriorly. The genital prores are four, the anterior two are smaller than the posterior ones.

The oral surface is nearly flat; the plastron is more or less elevated. The peristome is lunular in shape and eccentric anteriorly, nearer to the front than to the posterior margin of the test. The labrum is distinct, but never form a prominent lip. The periproct is small, subcircular in shape and situated at the summit of the posterior truncated surface. The peripetalous fasciole is continued very closely to the ambulacra, and the subanal fasciole bends adorally under the periproct. The test is fragile and grayish white in colour.

All the ambulacra are situated in narrow and shallow grooves. The odd anterior ambulacrum is petaloid and almost straight. The pores are small and 9 in number. Each of the anterior paired ambulacra forms a crescent-shaped figure with the posterior paired ones. The interporiferous zones of them are very narrow. The anterior paired ambulacra are divergent, forming an angle of $90^{\circ}$ between them at the apical system, and almost closed at their extremities. The pores are small and the pairs are conjugate. The posterior paired ambulacra are nearly as long as the anterior paired ones. They are parallel with each other, but curved outwards near the extremities. The pores are small and the pore pairs are 15 in number 
similarly as to the anterior paired ones.

The odd posterior interambulacrum is not elevated, forming a narrow strip. The interambulacra 1 and 4 form the narrow ridges between the anterior and posterior ambulacra.

The tubercles in the interambulacra and on the oral side are larger than those in the ambulacra and on the aboral side. There are many primary spines in the interambulacra on the oral side and along the ambulacra on the aboral side. The longest primaries attain $5 \mathrm{~mm}$.

Test Length:30.8 mm. Width:24.8 mm. Height:17.0 $\mathrm{mm}$.

Odd Amb. Length: $13 \mathrm{~mm}$. Width:2 mm.

Paired Amb. Length:7 mm. Width:2 mm.

Two other species of the genus Brissopsis are known from Japan and adjacent region, they are: Brissopsis oldhami Alcock, Brissopsis bengalensis KoEHLER.

Dredging station: Number:2. Position: $34^{\circ}-49.0^{\prime} \mathrm{N}, 138^{\circ}-47.8^{\prime} \mathrm{E}$, off Tago, Izu Peninsula. Depth:300m. Bottom:mud(soft). Abundancy:Many specimens were collected.

\section{Brissopsis bengalensis KOEHLER}

(Pl. XXV, Figs. 1-4)

1951 Brissopsis bengalensis. Th. Mortensen, A Monograph of the Echinoidea, V-2, P. 412, pls. XXX, fig. 6;XXXI, figs. 1, 2, 4;XXXIII, figs. 1-3;LIX, figs. 8, 9, 14, 15.

1968 Brissopsis bengalensis. S. NisiYama, The Echinoids Fauna from Japan and Adjacent Regions, II, P. 407.

Only one specimen of this species is at the writer's disposal.

The test is rather large in size, ovoid, more or less octagonal in outline, and notched at the anterior paired ambulacra. The frontal depression of the test is distinct.

The posterior end is truncate and somewhat concave. The test is not so low, with the greatest height at the posterior ambitus.

The apical system is small and central. The genital pores are four, the anterior two are somewhat smaller than the posterior pair.

The oral surface is somewhat swollen and the plastron is slightly elevated. The peristome is lunular in shape and eccentric, situated at the anterior one-fourth of the test length. The labrum is prominent. The periproct is elongate oval in shape and situated at the summit of the posterior truncated surface. The peripetalous fasciole is continued very closely to the ambulacra, and the subanal fasciole incurves adorally under the periproct. The test is fragile and brown in colour.

All the ambulacra are narrow, situated in shallow grooves, and petaloid. The odd anterior ambulacrum is straight. The pores are small and arranged in single series, The anterior paired ambulacra are divergent, forming an angle of $90^{\circ}$ 
between them at the apical system, and almost closed at their extremities. The pores are small and the pore pairs are conjugate. The posterior paired ambulacra are slightly shorter than the anterior ones, straight, divergent, forming an angle of $50^{\circ}$ between them at the apical system, and almost closed at their extremities. The interporiferous zones of the ambulacra are rather narrow. The ambulacra are developed into very remarkable phyllodes adorally.

The tubercles are larger on the oral side than on the aboral side, and so in the interambulacra than in the ambulacra. There are many primary spines in the interambulacra on the both sides. The largest primaries attain about $8 \mathrm{~mm}$ in length.

Test Length:54.8 mm. Width:50.3 mm. Height:33.3 mm.

Odd Amb. Length:19.3 mm. Width:2.9 mm.

Ant. Paired Amb. Length:15.0 mm. Width:2.8 mm.

Post. Paired Amb. Length:13.0 mm. Width:2.7 mm.

Two other species of the genus Brissopsis are known from Japan and adjacent region, they are: Brissopsis luzonica (GRAY), Brissopsis oldhami Alcock.

Dredging station: Number:2. Position: $34^{\circ}-40.7^{\prime} \mathrm{N}, 138^{\circ}-23.6^{\prime}$ E, around Senoumi. Depth:510-580 m. Bottom:mud(solid).

\section{Genus Gymnopatagus DöDERLEIN}

\section{Gymnopatagus valdiviae DöDERLEIN}

(Pl. XXV, Figs. 8-9)

1951 Gymnopatagus valdiviae. Th. Mortensen, A Monograph of the Echinoidea, V-2, p. 447.

Only a single specimen of this species is at the writer's disposal. The left-posterior quarter of the aboral and the posterior three-fourths of the oral side are broken.

The test is rather large in size and elliptical in outline, with a deep notch at the anterior edge. It is low, broad anteriorly, and narrowing posteriorly, and with the greatest width at the posterior paired interambulacra. The apical system is eccentric anteriorly. The genital pores are four.

The oral surface is nearly flat, not sunken towards the peristome. The peristome is eccentric anteriorly, slender transversely, and somewhat crescent-shaped. There is a distinct peripetalous fasciole. The test is very fragile and white in colour.

The ambulacral area is rather narrow, limited anteriorly, and flush with the general surface of the test. The odd anterior ambulacrum is a single series and almost straight. The pres are small and 6 in number. The paired ambulacra are conspicuously petaloid, slightly open at the extremities, and almost equal in length. Near the extremities the anterior paired ambulacra are divergent, while the posterior ones are convergent very slightly. Their pores are conjugate and 13 in number. The interporiferous zones are moderate throughout all the ambulacra. The posterior paired inter ambulacra are the broadest of all. 
The large tubercles and spines are very few and confined only within the peripetalous fasciole, except for the odd posterior interambulacrum which is wholly devoid of them. The longest primary spines attain about $12 \mathrm{~mm}$.

Test Length:about $57 \mathrm{~mm}$. Width:47..0 mm. Height:18.2 mm.

Odd Amb. Length:18.7 mm. Width:5.5 mm.

Ant. Paired Amb. Length:11.6 mm. Width:3.8 mm.

Post. Paired Amb. Length:10.8 mm. Width:3.5 mm.

According to S. Nisiyama, Gymnopatagus magnus A. Agassiz and H. L. Clark has been the only species of this genus from Japan and adjacent region. The present second species differs from Gymnopatagus magnus in the absence of large primary tubercles in the odd posterior interambulacrum on the aboral side and in having pore pairs distinctly conjugate.

Dredging station: Number:10. Position: $34^{\circ}-43.0^{\prime} \mathrm{N}, 138^{\circ}-28.8^{\prime} \mathrm{E}$, Senoumi. Depth:180-230 m. Bottom :shell and granule sand. Abundancy:Only one specimen was collected.

\section{References}

Agassiz, A. (1879): Preliminary report on the "Challenger" echini. Proc. Amer. Acad. Arts \& Sci., 14, p. 205.

(1881): Report on the echinoidea dredged by H.M.S. Challenger during the years 1873-76. Rep. Cballenger-Expedition, Zool., 3(9), pp. 175, 189, 202, pls. 22, figs. 7-15; 31, figs. 1-6; 36, figs. $8-13$; 39, figs. 13 , 35; 40, figs. 45-46, 61-62; 41, fig. 53 ; 43, fig. 26 ; 65, figs. 7-10.

Аокт, H., Yoshinara, T. and Hoshino, M. (1967): Geology of the Suruga Bay (Part 1), Submarine Distribution of Gravels, Jour. Fac. Oceanogr., Tokai Univ., 2, p. 85.

Clark, H.L. (1912): Hawaiian and other Pacific echini, Mem. Mus. Comp. Zool., 34 (4), pp. 221, 274. pls. 91, figs. $14-17 ; 105$, fig. 8.

(1914): Hawaiian and other Pacific echini, ibid., 46 (1), pls. 124, figs. 13-16; 127, figs. 7-8;

140, figs. $3-4$; 141, figs. $4-9$.

(1923): The Echinoderm Fauna of South Africa, Ann. South African Mus., 13(2), p. 404.

(1924): Echinoderms from the South African Fisheries and Marine Biological Survey, Part

1, Sea-Urchins (Echinoidea), Fish. and Mar. Biol. Surv. Union South Africa, Rep., 4, p. 12

(1925): A Catalogue of the Recent Sea-Urchins (Echinoidea) in the Collection of the British Museum (Natural History). London, pp. 158, 192, 210, 213, 230.

DöDERLEIN, L. (1885): Seeigel von Japan und Liukiu Inseln, Archiv für Naturgesch., 51, pp. 24, 32, $35,36,76$.

Gregory, J.W. (1906): Fossil Echinoidea from Sinai and Egypt, Geol. Mag., London, dec. 5, 3, p. 255.

IKEDA, H. (1931): Morphological Change occurring with the Growth of the Calcareous Test in Heart-Urchins, Lovenia elongata (Gray): I, On the Increase of the Dorsal Primary Spines, Annot. Zool. Japan., 13(3), p. 243, pl. 14.

- (1933): Note on a Single-Spines Specimen of the Heart-Urchins, Lovenia elongata (GRAY), ibid., 14(1), p. 47.

Jeannet, A. und Martin, R.: Ueber Neozoische Echinoidea aus dem Niederländisch-Indischen Archipel, Leid. Geol. Mededdel., 8, p. 250.

Mortensen, Th. (1904): The Danish Expedition to Siam, 1899-1900, II, Echinoidea, Part 1, Mem. Acad. Roy. Sci., Copenhague, ser. 7, 1, p. 34, pls. III, figs. 12; IV, 3, 5, 6. 
(1914): On the Development of Some Japanese Echinoderms, Annot. Zool. Japon., 8, p. 547. (1928): A Monograph of the Echinoidea I, Cidaroidea, p. 280, pls. 28, figs. 1-10; 70, fig. 8; 82, figs. $11-17$.

(1940): A Monograph of the Echinoidea, III-1, Aulodonta, p. 99, pls. II, figs. 13-15; III, fig.

2; LXVI, figs. 10-22; LXVII, fig. 17.

(1943): A Monograph of the Echinoidea III-2, Camarodonta-I, p. 238, pls. XVII, figs. 25-28;

XLVII, fig. 28.

(1948): A Monograph of the Echinoidea IV-2, Clypeastroida, p. 338, pls. LIV, figs. 5-6,

10-13; LXX, figs. 8-9. 14-15.

(1950): A Monograph of the Echinoidea V-1, Spatangoida I, p. 147.

(1951): A Monograph of the Echinoidea V-2, Spatangoida II, pp. 97, 300, 397, 412, pls. VII,

figs. 1-10; VIII, fig. I; XII, fig. 5; XXI, figs. 5-10, 14-18; XXX, fig. 6; XXXI, figs. 1, 2, 4;

XXXII, figs. 2-4, 12-14, 19, 21 ; XXXIII, figs. 1-3; XXXIX, fig. 12; XLVII, figs. 10-23; LIV,

figs. 1-3, 5, 7-9, 12, 14-17; LVI, figs. 2, 4, 5, 8-11, 13-15, 18-29; LIX, figs. 8, 9, 14, 15.

Nisryama, S. (1937): Annotated List of Echinoids dredged from the Pacific Coast of Tiba Prefecture,

Rec. Oceanogr. Works, Japan, 9(1), pp. 50, 56.

(1968): The Echinoids Fauna from Japan and Adjacent Regions, part II, Palaeon. Soc. Japan,

Spec. Papers, 13, pp. 71, 319, 328, 375, 387, 397, 406, 407.

Orada, Y., Sakamoto, I., Amano, R. and Tominaga, Y. (1966): Preliminary Report of the Benthic

Biological Survey in Suruga Bay, Jour. Fac. Oceanogr., Tokai Univ., 1, 135.

Tokunaga, S. (1903): Fossil Echinoids of Japan, Jour. Coll. Sci., Tokyo, 17(12), p. 11.

Utinomi, H. (1954): A Check List of Echinoids found in the Kii Region, Publ. Seto Mar. Biol. Lab., III (3), pp. 341, 343, 354-356.

Yoshiwara, S. (Tokunaga, S.) (1898): Japanese Echinoids (in Japanese), Zool. Mag., 10, pp. 57, 330.

- (1900): Japanese Echinoids, ibid., 12, pp. 398, 405.

(1904): Japanese Echinoids, ibid., 16, pl. 1, figs. 8-10.

- (1905): Japanese Echinoids, ibid., 17, pl. 5, fig. 5.

(1907): Japanese Echinoids, ibid., 19, pls. 16, figs. 1-4; 17, figs. 10-14; 19, figs. 7-10.

(1908): Japanese Echinoids, ibid., 20, pl. 21, figs. 5-8, 15-17. 


\section{EXPLANATION OF PLATES XXI-XXV}

(All figures in natural size)

$$
\text { Plate XXI }
$$

Stereocidaris japonica (DöderLeIN)

Fig. 1. Aboral side. Fig. 2. Oral side.

\section{Plate XXII}

Stereocidaris japonica (DöDERLEIN)

Fig. 1. Aboral side. Fig. 2. Oral side.

Caenopedina mirabilis (DöDERLEIN)

Fig. 3. Aboral side. Fig. 4. Oral side.

\section{Plate XXIII}

Pseudechinus huttoni BenHAM

Fig. 1. Aboral side. Fig. 2. Lateral side. Fig. 3. Oral side.

\section{Plate XXIV}

Laganum fudsiyama DöDERLEIN

Fig. 1, 3. Aboral side. Fig. 2, 4. Oral side.

Pourtalesia laguncula A. AgAssiz

Fig. 5. Aboral side. Fig. 6. Oral side.

Lovenia elongata (GRAY)

Fig. 7. Aboral side. Fig. 8. Oral side. Fig. 9. Lateral side.

Schizaster lacunosus (LinNAEus)

Fig. 10. Aboral side. Fig. 11. Oral side. Fig. 12. Lateral side.

\section{Plate XXV}

Brissopsis bengalensis KoEHLER

Fig. 1. Aboral side. Fig. 2. Oral side. Fig. 3. Lateral side. Fig. 4.

Posterior side.

Brissopsis luzonica (GRAY)

Fig. 5. Aboral Side. Fig. 6. Lateral side. Fig. 7. Oral side.

Gymnopatagus valdiviae DöDerLeIN

Fig. 8. Aboral side. Fig. 9. Oral side. 


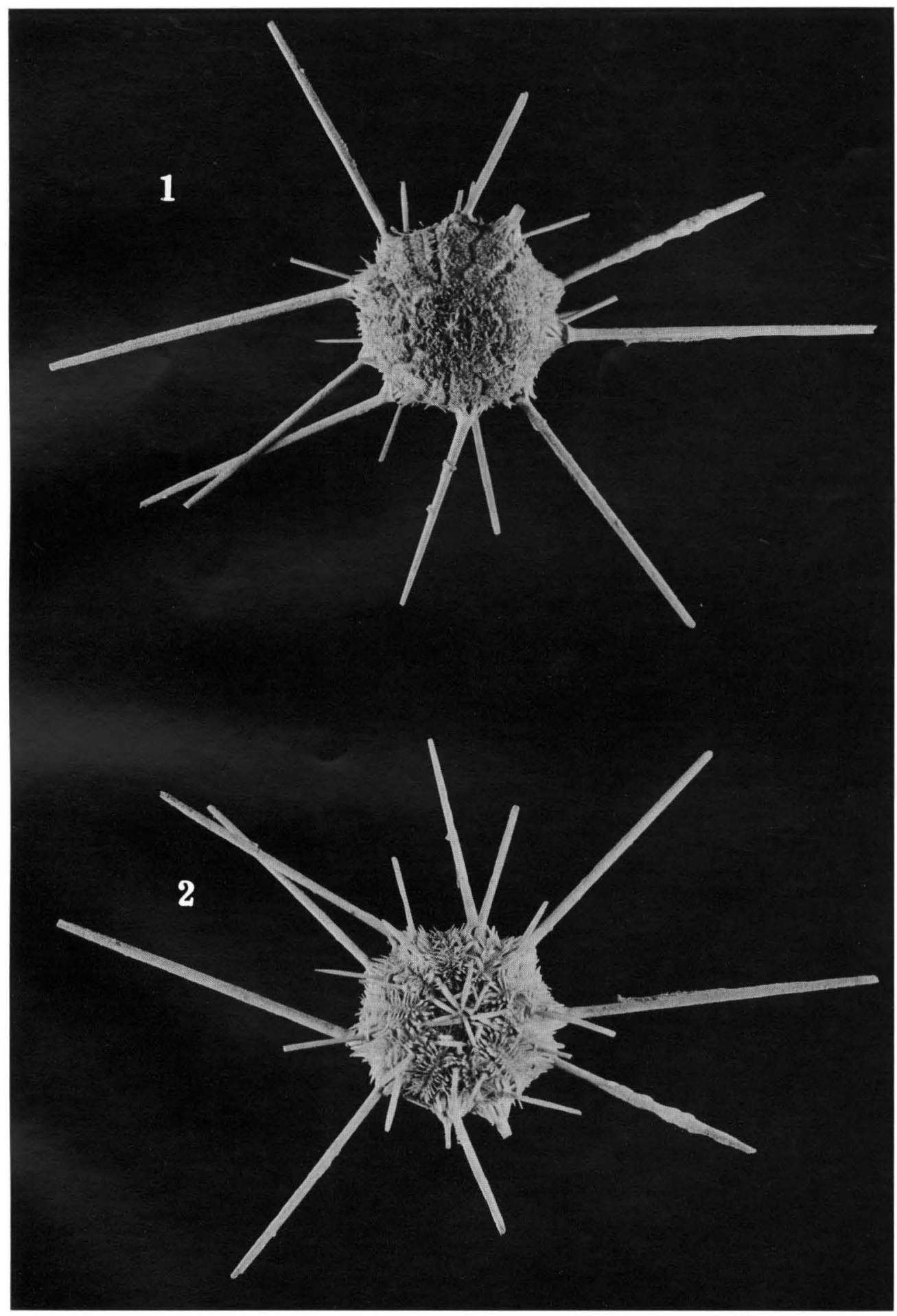

A. Morishita : Echinoids in Suruga Bay 


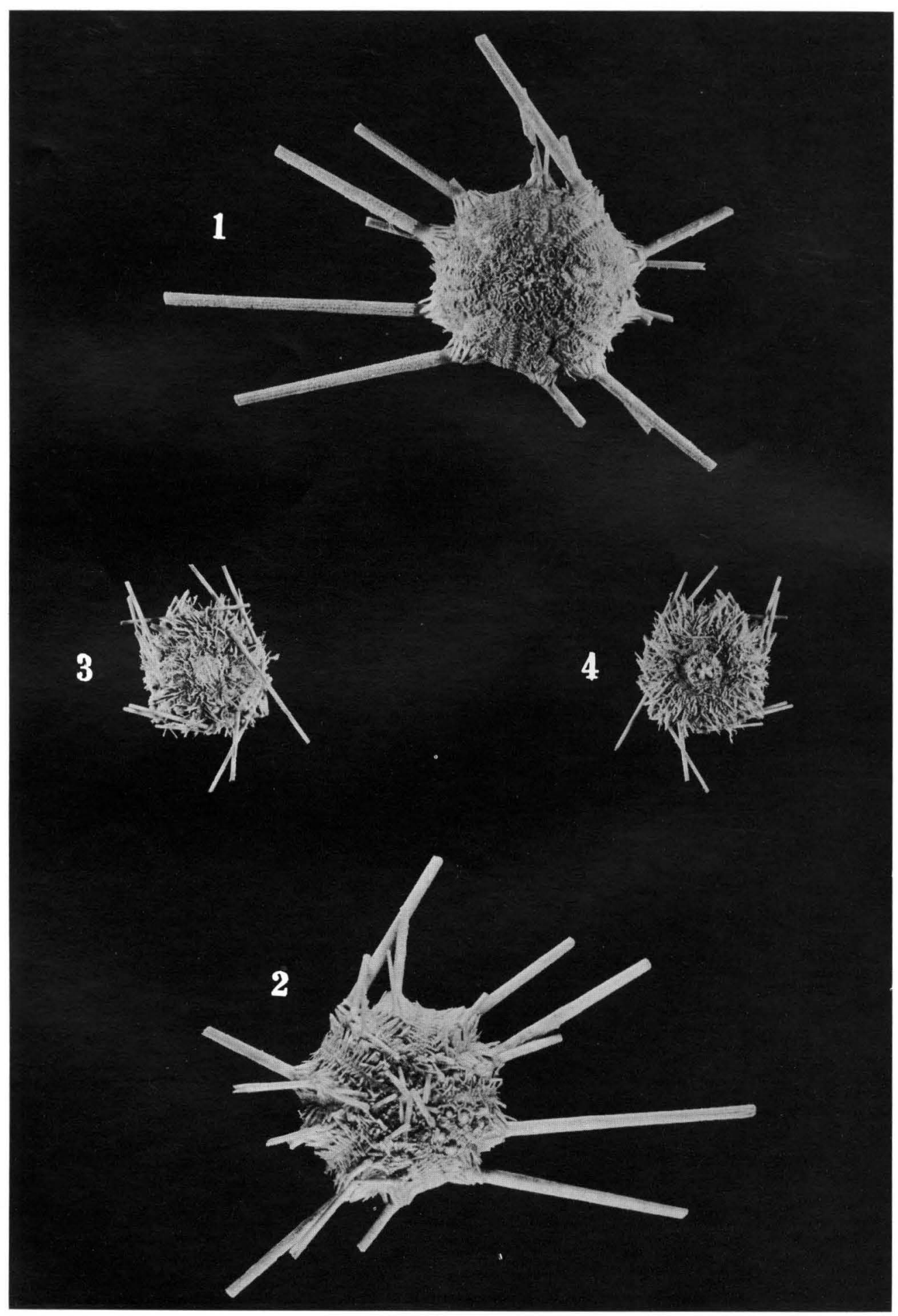

A. Morishita : Echinoids in Suruga Bay 


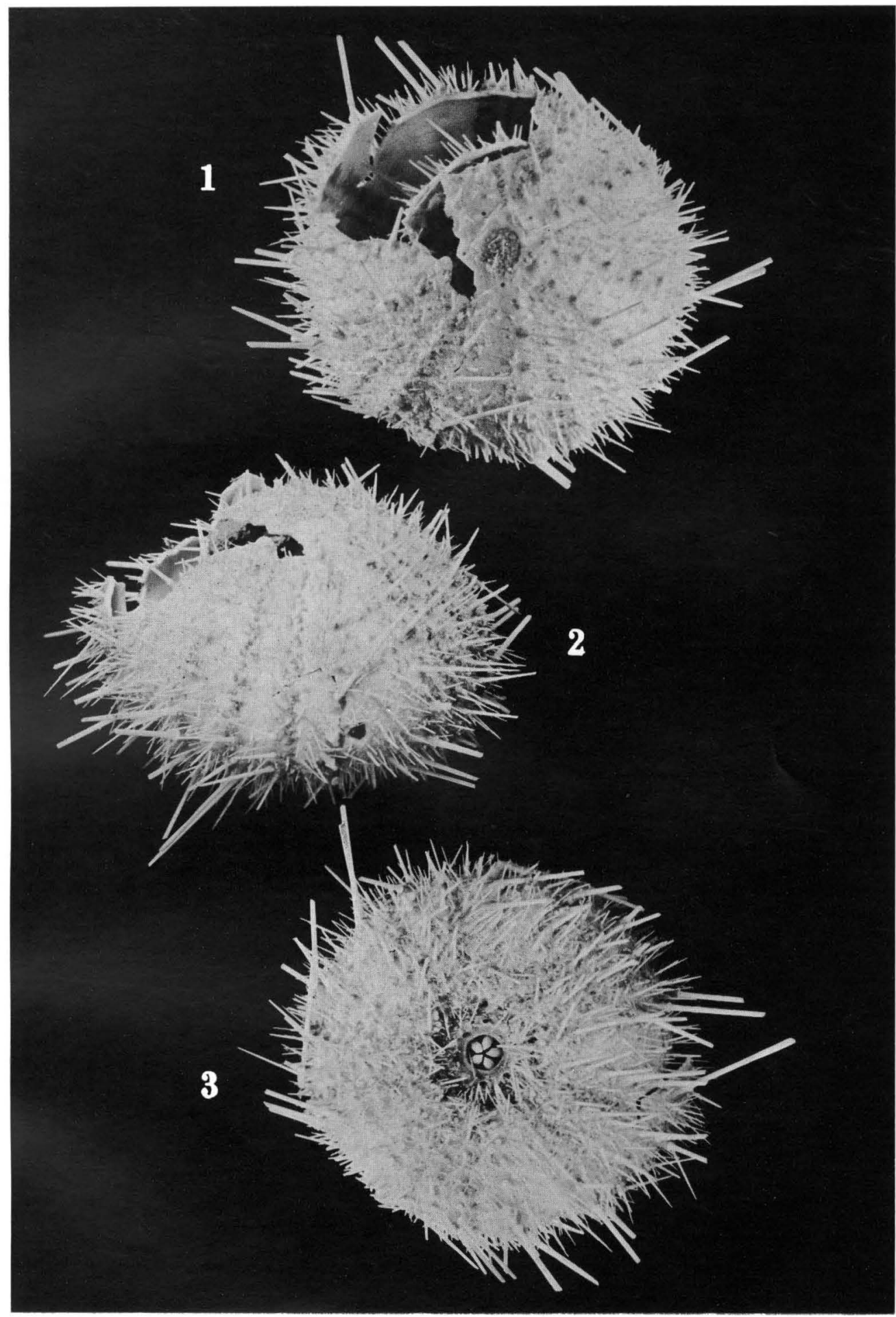

A. Morishita : Echinoids in Suruga Bay 
Publ. Seto Mar. Biol. Lab., XVI (6), 1969.

PLATE XXIV
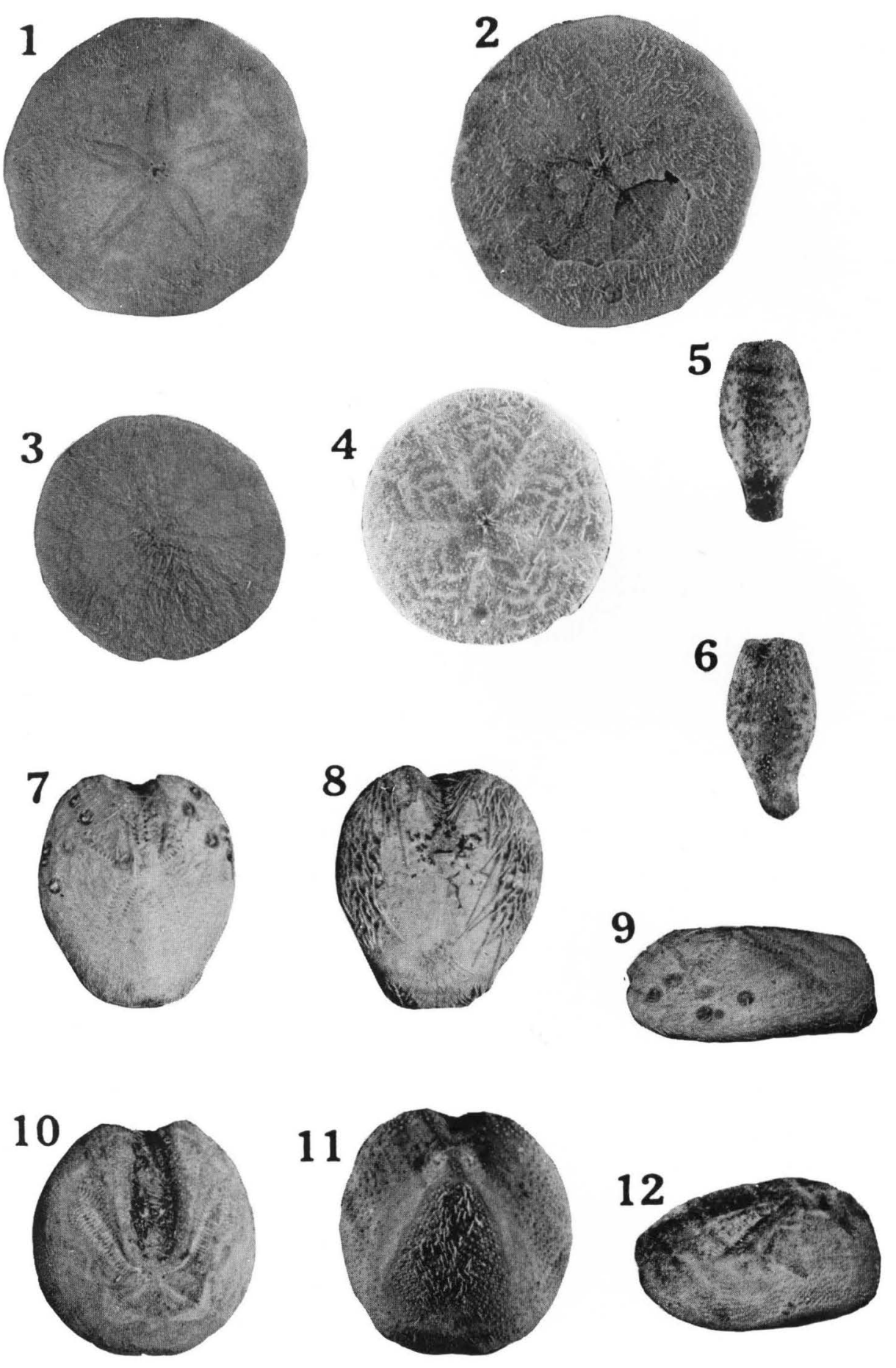

A. Morishita : Echinoids in Suruga Bay 
Publ. Seto Mar. Biol. Lab., XVI (6), 1969.

PLATE XXV
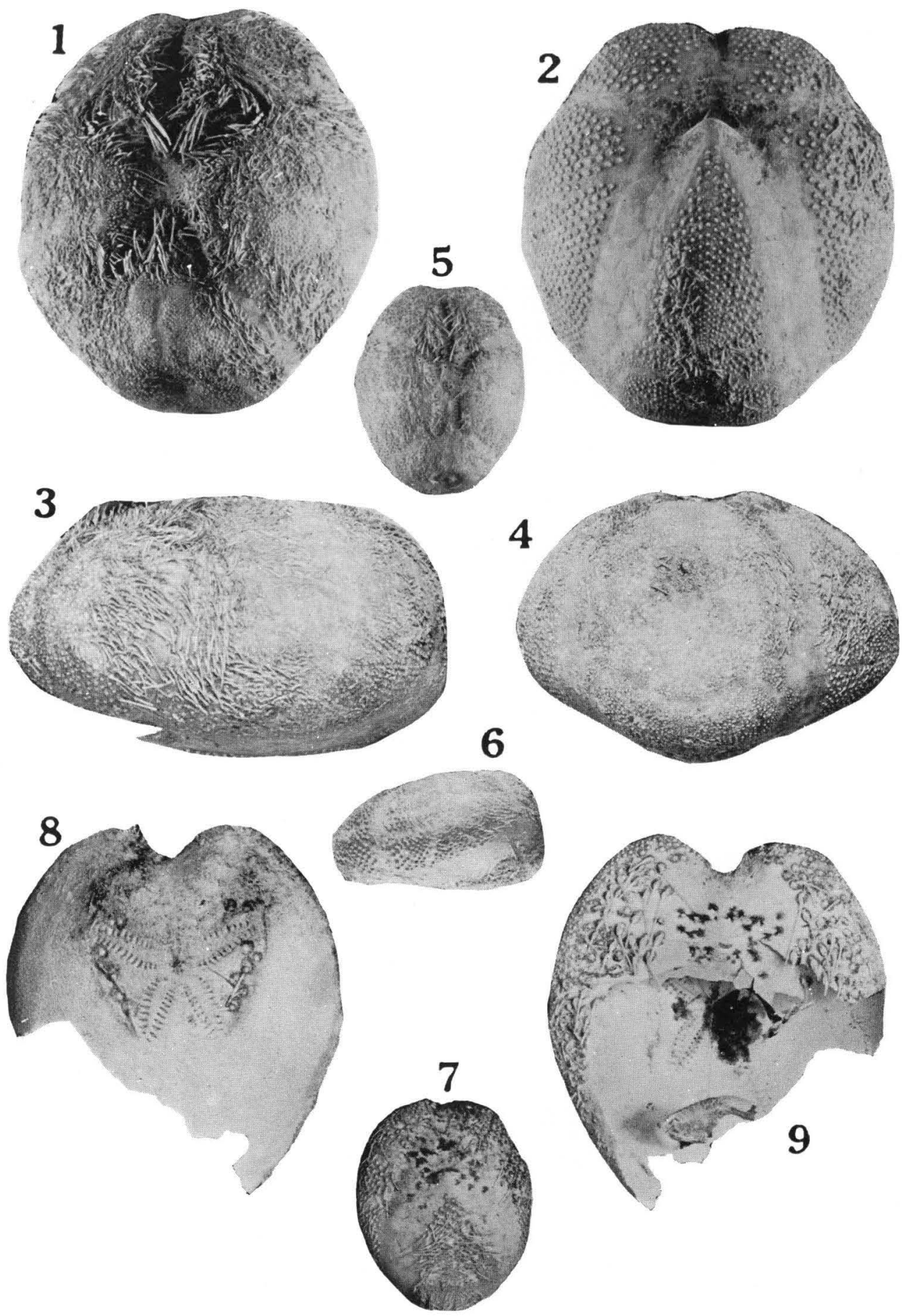

A. Morishita : Echinoids in Suruga Bay 